\title{
Study of the Effect of Gibberellins on some Physi- ologic Processes of Corn Plants (Zea Mays)
}

\author{
Lucia MIHALESCU ${ }^{1}$, Oana MARE ROŞCA ${ }^{1}$, Zorica VOȘGAN ${ }^{1}$, Monica MARIAN ${ }^{1}$, Aurel MAXIM ${ }^{2}$, Mirela \\ CORDEA $^{2}$, Beatrice SZILAGYI ${ }^{2}$ \\ ${ }^{1}$.Department of Biology. Technical University of Cluj Napoca, North University Center of Baia Mare, \\ no.76 Victoriei Street, Baia Mare, Romania; \\ ${ }^{2}$ University of Agricultural Sciences and Veterinary Medicine, Cluj-Napoca \\ * corresponding author: luciamihalescu@yahoo.com
}

Bulletin USAMV series Agriculture 71(2)/2014

Print ISSN 1843-5246; Electronic ISSN 1843-5386

DOI 10.15835/buasvmcn-agr: 10549

\begin{abstract}
The current trend on the environment protection is to use some techniques of obtaining some efficient cultures using fertilizers in agriculture. Taking into account of these aspects, we considered necessary addressing some research on the influence of growing hormones on the growing processes of plants. The aim of this research was obtaining some results meant to lead to the increase of the mineral nutrition conditions of plants. Gibberellins are natural stimulants of plants growth and development, with often spectacular effects, which due to the remarkable results found in the agricultural and horticultural production enjoy a special attention of the specialists. The aim of this study was to follow the effect of gibberellic acid of different concentrations on the germination, the dynamics of the growth of roots, stems, the intensity of perspiration and respiration of corn seedlings. The used variants were: $V_{1}$ - control sample, $V_{2}-0.1 \mathrm{mg} / \mathrm{l}, \mathrm{V}_{3}-1 \mathrm{mg} / \mathrm{l}, \mathrm{V}_{4}-2 \mathrm{mg} / \mathrm{l}, \mathrm{V}_{5}-5 \mathrm{mg} / \mathrm{l}$ of giberellic acid. Subsequent to the analysis of the data obtained from the performed experience, one can state that the germination is positively influenced; the growth rate of stems has higher values as in case of roots. The stems are higher and thinner, the leaves become light green, the main root and the side ones are thin and long. Also, the intensity of perspiration uniformly increases from the control sample to the $V_{5}$ variant ( $5 \mathrm{mg} / \mathrm{l}$ gibberellic acid), being correlated with the increased phytohormone concentration.
\end{abstract}

Keywords: gibberellins, influence, root, stem

\section{INTRODUCTION}

Gibberellins have an important role in the regulation of the processes of growth and development of plants, being increasingly used in agriculture and horticulture (Gadea, 2003). Phytohormones are biosynthesized in cytoplasm of young cells, they accumulate in the growing areas of root, stem, buds, etc. (Bandici, 2006). The contents of gibberellins of fruits and unripe seeds are two times higher than in the rest of vegetative organs (Trifu and Barbat, 1997). Gibberellins stimulate the splitting up and elongation of vegetal leaves (Dobrota and Yamashita, 1999).

\section{MATERIALS AND METHODS}

In order to study the effect of gibberellic acid on the growing and development of corn plants, solutions of different concentrations of gibberellic acid were prepared, and the variants that were used are as it follows: $V_{1}$ - control sample, $\mathrm{V}_{2}-0.1 \mathrm{mg} / \mathrm{l}, \mathrm{V}_{3}-1 \mathrm{mg} / \mathrm{l}, \quad \mathrm{V}_{4}-2 \mathrm{mg} / \mathrm{l}, \quad \mathrm{V}_{5}-$ $5 \mathrm{mg} / \mathrm{l}$ of giberellic acid. The used caryopses belonged to the Dobrogean variation. They were daily wetted with the appropriate solutions, and the control sample with tape water. The energy and germinative faculty were calculated; using linear measuring for 16 days the growth of roots and stems was surveyed and the dynamics of their growth was calculated. The values obtained by biometric measuring were statistically processed, calculating the arithmetic average, standard error and deviation, and for determining the statistic significance of the obtained results the Student's $t^{\prime}$ test was used. The perspiration was estimated 
using the method of ascertaining the water vapors eliminated in the confined atmosphere, and the respiration was estimated using the BoysenJensen method.

\section{RESULTS AND DISCUSSION}

We noted that germination was influenced by the presence of gibberellic acid, as it was $95 \%$ at $\mathrm{V}_{5}$, respectively, with approximately $15 \%$ higher than that of the untreated control sample. The variants $\mathrm{V}_{2}-0.1 \mathrm{mg} / \mathrm{l}$ of gibberellic acid and $\mathrm{V}_{4}$ $2 \mathrm{mg} / \mathrm{l}$ had the same germination rate of $90 \%$. Therefore the stimulative effect of gibberellic acid on the germination process was noticed. Further we followed the growth process of corn seedlings roots during 16 days; measurements were made every other day. The averages of the determinations performed in case of roots a shown in Tab.1.

We notice that on the $16^{\text {th }}$ day the growth of the variant $V_{2}$ is higher with $27.77 \%$ than that of the control sample, the growth of the variant $V_{3}$ is higher with $76.38 \%$, the growth of the variant $V_{4}$ is higher with $91.66 \%$. A much better picture of the roots growth is offered examining the growth rate, as it is shown in figure 1.

The growth rate was determined in the days: A-4/6; B-6/8; C-8/10; D-10/12; E-12/14; F-14/16.

In Fig.1 we notice that the growing process stronger triggers during the period of the days $6-8$, the growth rate being significantly higher during this determination interval. The growth rate during the days 8-10 recorded lower values, and the last 3 growth rates determined for every variant come after each other in decreasing order.

In case of stems the determinations averages for every variant is observed in Tab.2.

In Tab. 2 we notice that in the $16^{\text {th }}$ day the variant $V_{2}$ presented a growth higher with $27.61 \%$ than the control sample, the variant $\mathrm{V}_{3}$ with $59 \%$, $\mathrm{V}_{4}$ with $70.47 \%$, and $\mathrm{V}_{5}$ with $90.47 \%$.

The growth rate of stems $(\mathrm{cm} / 48 \mathrm{~h})$ is shown in Fig.2.

The growth rate was determined in the days: A-4/6; B-6/8; C-8/10; D-10/12; E-12/14; F-14/16.

We notice that the growth process of stems is more intense during the interval of the $10^{\text {th }}-12^{\text {th }}$ day, when the growth rate was significan-

Tab.1. Averages of the determinations performed in case of roots, for every experimental variant

\begin{tabular}{|c|c|c|c|c|c|}
\hline $\begin{array}{c}\text { Age of } \\
\text { plantlet } \\
\text { [days] }\end{array}$ & $\begin{array}{c}\mathrm{V}_{1} \\
\text { untreated } \\
\text { control }\end{array}$ & $\begin{array}{c}\mathrm{V}_{2} \\
0.1 \mathrm{mg} / 1 \\
\text { giberellic } \\
\text { acid }\end{array}$ & $\begin{array}{c}\mathrm{V}_{3} \\
1 \mathrm{mg} / 1 \\
\text { giberellic } \\
\text { acid }\end{array}$ & $\begin{array}{c}\mathrm{V}_{4} \\
2 \mathrm{mg} / 1 \\
\text { giberellic } \\
\text { acid }\end{array}$ & $\begin{array}{c}\mathrm{V}_{5} \\
5 \mathrm{mg} / 1 \\
\text { giberellic } \\
\text { acid }\end{array}$ \\
\hline 4 & 0.6 & 1.2 & 1.5 & 2.0 & 2.3 \\
\hline 6 & 1.7 & 2.1 & 3.0 & 3.8 & 3.9 \\
\hline 8 & 4.0 & 4.4 & 6.4 & 6.7 & 6.9 \\
\hline 10 & 5.0 & 5.2 & 7.3 & 7.9 & 7.5 \\
\hline 12 & 6.1 & 6.9 & 9.6 & 10.5 & 10.7 \\
\hline 14 & 7.0 & 8.4 & 11.6 & 12.3 & 12.5 \\
\hline 16 & 7.2 & 9.2 & 12.7 & 13.8 & 14.0 \\
\hline
\end{tabular}

Tab. 2. Average height of stems $(\mathrm{cm})$ of corn seedlings grown on different environment variants

\begin{tabular}{|c|c|c|c|c|c|}
\hline $\begin{array}{c}\text { Age of } \\
\text { plantlet } \\
\text { [days] }\end{array}$ & $\begin{array}{c}\mathrm{V}_{1} \\
\text { control } \\
\text { untreated }\end{array}$ & $\begin{array}{c}\mathrm{V}_{2} \\
0.1 \mathrm{mg} / 1 \\
\text { giberellic } \\
\text { acid }\end{array}$ & $\begin{array}{c}\mathrm{V}_{3} \\
1 \mathrm{mg} / 1 \\
\text { giberellic } \\
\text { acid } \\
\end{array}$ & $\begin{array}{c}\mathrm{V}_{4} \\
2 \mathrm{mg} / 1 \\
\text { giberellic } \\
\text { acid }\end{array}$ & $\begin{array}{c}\mathrm{V}_{5} \\
5 \mathrm{mg} / 1 \\
\text { giberellic } \\
\text { acid } \\
\end{array}$ \\
\hline 4 & 1.0 & 1.1 & 1.5 & 2.2 & 2.3 \\
\hline 6 & 2.7 & 2.5 & 2.9 & 3.4 & 3.8 \\
\hline 8 & 5.1 & 4.2 & 6.4 & 6.8 & 6.9 \\
\hline 10 & 6.2 & 5.2 & 7.1 & 7.7 & 8.3 \\
\hline 12 & 8.8 & 9.6 & 11.2 & 12.0 & 13.5 \\
\hline 14 & 9.3 & 11.9 & 13.5 & 14.6 & 16.2 \\
\hline 16 & 10.5 & 13.4 & 16.7 & 17.9 & 20.0 \\
\hline
\end{tabular}




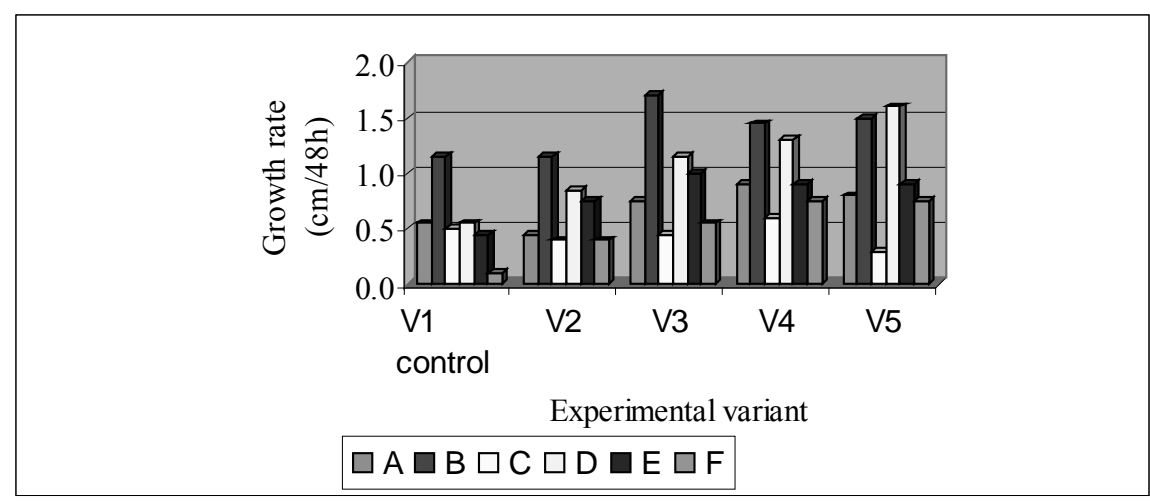

Fig.1. Growth rate of corn seedlings roots.

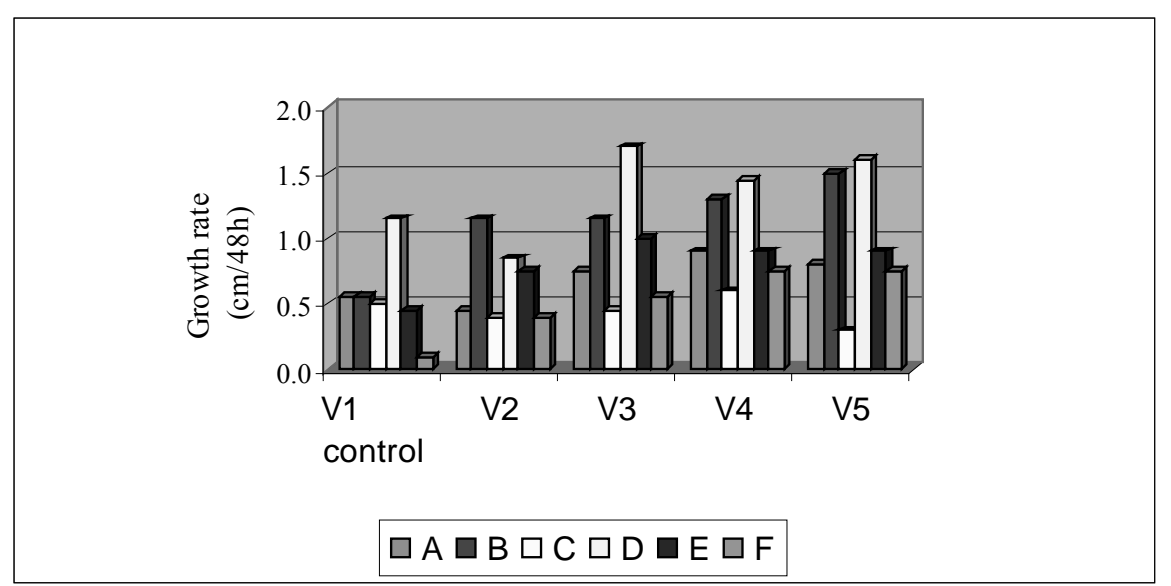

Fig.2. Growth rate of corn seedlings stems

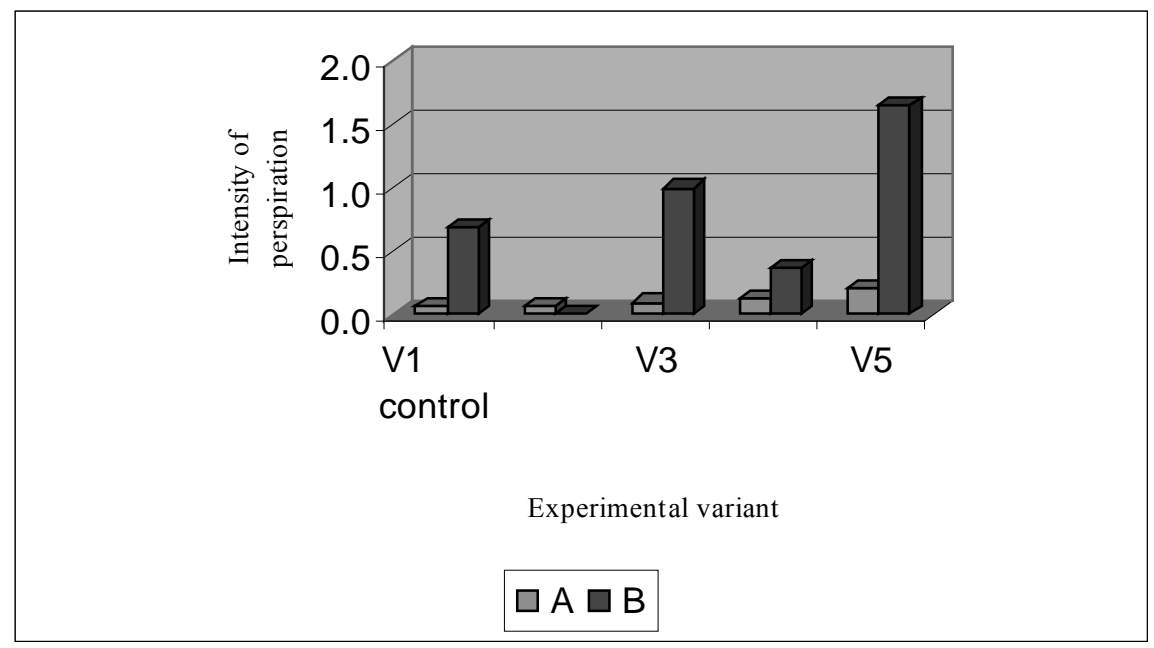

Fig.3. Intensity of perspiration of corn seedlings of the analyzed variants

tly higher. In every variant, an obvious decrease of growth result during the interval of the $8^{\text {th }}-10^{\text {th }}$ days.

The results obtained on the intensity of perspiration relative to the weight of fresh and dried out vegetal material are shown in Fig.3.
It is noticed that the intensity of the perspiration process uniformly increases from the control sample towards the $V_{5}$ variant $(5 \mathrm{mg} / \mathrm{l}$ gibberellic acid); this variant offers the larger perspiration surface, being correlated with the high concentration of phytohormone. For this 
Tab. 3 The influence of the treatment with the solutions of gibberellic acid on the respiration intensity, respectively on the amount of $\mathrm{CO}_{2}$ produced after three days of treatment

\begin{tabular}{|c|c|c|c|c|c|c|}
\hline Item & Variant & $\begin{array}{c}\text { Weight of } \\
\text { fresh } \\
\text { vegetal } \\
\text { material } \\
(\mathrm{g}) \\
\end{array}$ & $\begin{array}{c}\text { Weight of } \\
\text { dried out } \\
\text { vegetal } \\
\text { material } \\
(\mathrm{g})\end{array}$ & $\begin{array}{c}\text { Oxalic acid } \\
\text { used for } \\
\text { titration } \\
\text { (ml) }\end{array}$ & $\begin{array}{c}\mathrm{cm}^{3} \mathrm{CO}_{2} / \mathrm{g} \\
\text { fresh } \\
\text { substance } / \mathrm{h}\end{array}$ & $\begin{array}{c}\mathrm{cm}^{3} \mathrm{CO}_{2} / \mathrm{g} \\
\text { dried out } \\
\text { substance/h }\end{array}$ \\
\hline 1 & \begin{tabular}{|c|}
\multicolumn{2}{|c|}{ Control } \\
sample
\end{tabular} & 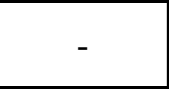 & $x_{1}$ & 10.0 & - & - \\
\hline 2 & $\begin{array}{c}\text { Control } \\
\text { sample II }\end{array}$ & 1.91 & 0.22 & 6.4 & 1.88 & 16.36 \\
\hline 3 & $\begin{array}{c}\mathrm{V}_{2} \\
0.1 \mathrm{mg} / 1 \\
\text { giberellic } \\
\text { acid } \\
\end{array}$ & 2.15 & 0.25 & 5.5 & 2.09 & 18.00 \\
\hline 4 & $\begin{array}{c}\mathrm{V}_{3} \\
1 \mathrm{mg} / 1 \\
\text { giberellic } \\
\text { acid } \\
\end{array}$ & 2.9 & 0.34 & 3.5 & 2.24 & 19.11 \\
\hline 5 & $\begin{array}{c}\mathrm{V}_{4} \\
2 \mathrm{mg} / 1 \\
\text { giberellic } \\
\text { acid } \\
\end{array}$ & 3 & 0.35 & 3.0 & 2.33 & 20.00 \\
\hline 6 & $\begin{array}{c}\mathrm{V}_{5} \\
5 \mathrm{mg} / 1 \\
\text { giberellic } \\
\text { acid }\end{array}$ & 3.23 & 0.38 & 2.0 & 2.47 & 21.05 \\
\hline
\end{tabular}

variant, the intensity of perspiration is 3.66 times higher than that of the control sample.

The last monitored parameter was the determination of the respiration intensity; the obtained results are noticed in Tab.3.

The value of the respiration intensity is the highest for the plants grown on the richest in gibberellic acid environment $(5 \mathrm{mg} / \mathrm{l})$. The explanation could be the effect of gibberellic acid on the intensifying of all the physiological processes in plant organs. For example, in plant green organs, where photosynthesis is made, a more intense catabolism takes place that means higher oxygen consumption. The respiration intensity linearly decreases at plants belonging to the other variants, respectively $2 \mathrm{mg} / \mathrm{l}, 0.1 \mathrm{mg} / \mathrm{l}$, and control sample, due to the concentration decrease in the respective gibberellic acid solutions.

\section{CONCLUSION}

The highest germination percentage was at the variant with the highest content of gibberellic acid $V_{5}(5 \mathrm{mg} / \mathrm{l})$, a stimulation of the germination capacity of $15 \%$ being produced, comparatively with the untreated control sample.

In case of plants growing process, the action of phytohormones is a stimulating of the process, and this is more obvious as the hormone concentration is higher and the plant is in an advanced growing status.

Treating plants with gibberellic acid morphologic modifications appear which depend on the hormone concentration, i.e. the stems are higher and thinner, the leaves become light green, the main root and the side ones are thin and long.

The intensity of perspiration uniformly increases from the control sample to the $V_{5}$ variant ( $5 \mathrm{mg} / \mathrm{l}$ gibberellic acid), being correlated with the increased phytohormone concentration.

In the respiration process the respiration intensity of the seedlings grown on environment ( $5 \mathrm{mg} / \mathrm{l}$ gibberellic acid) is higher with $31 \%$ than the control sample seedlings, as gibberellic acid has an important role in the biochemical processes in seedling cells. 


\section{REFERENCES}

1. Bandici G (2006). Fiziologia plantelor, Editura Universitatii din Oradea. 97-102.

2. Gadea S (2003). Fiziologia vegetala, Editura A. Press, Clcuj-Napoca. 53-55.
3. Dobrota C and Yamashita M (1999). Cresterea si dezvoltarea plantelor. Casa de Editura Gloria Cluj. 20-21

4. Trifu M and Barbat I (1997). Fiziologia plantelor. Ed. Viitorul Romanesc Bucuresti. 39-41 